ppi $201502 Z U 4645$

Esta publicación científica en formato digital es continuidad de la revista impresa ISSN-Versión Impresa 0798-1406 / ISSN-Versión on line 2542-3185Depósito legal pp $197402 Z$ U34
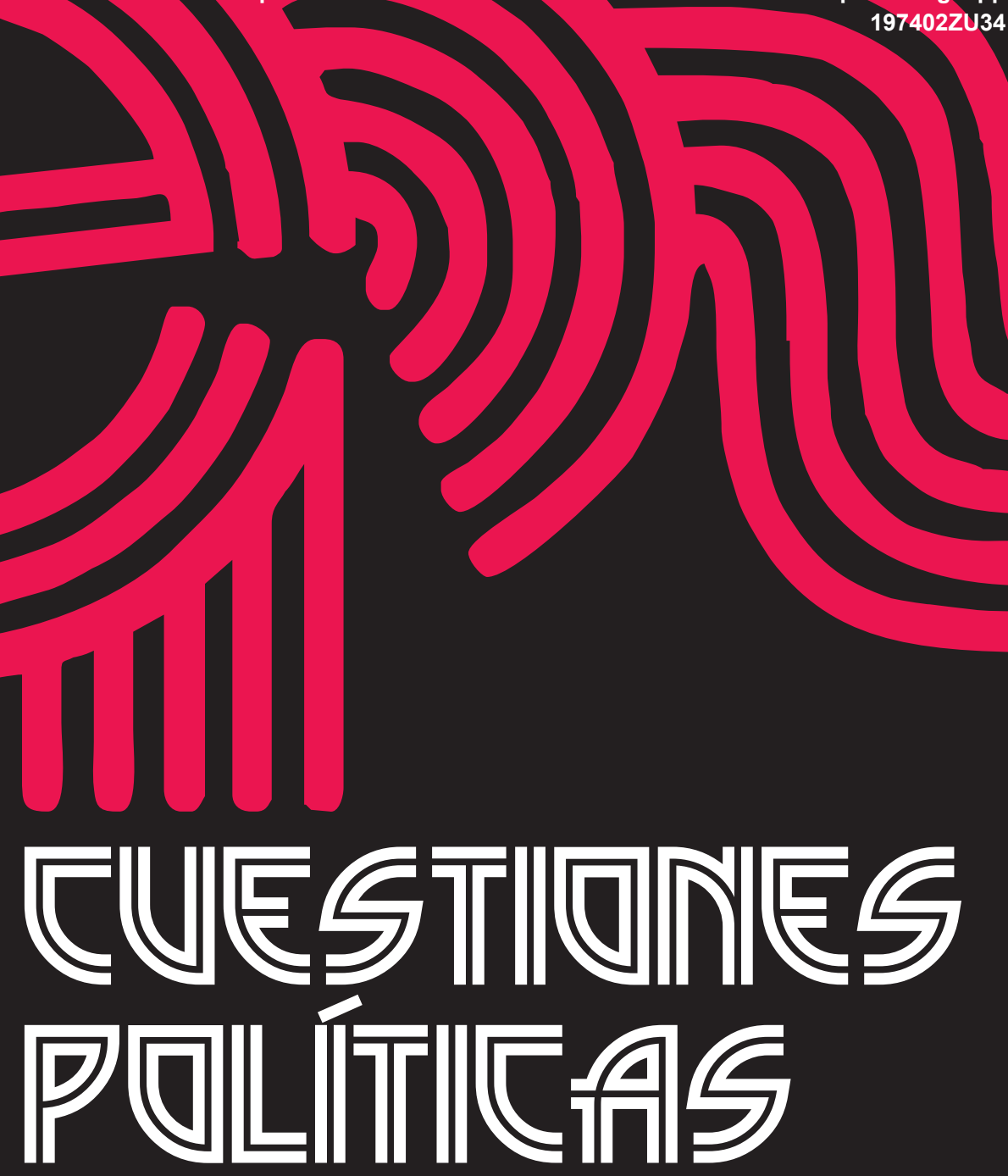

Instituto de Estudios Políticos y Derecho Público "Dr. Humberto J. La Roche" de la Facultad de Ciencias Jurídicas y Políticas de la Universidad del Zulia Maracaibo, Venezuela
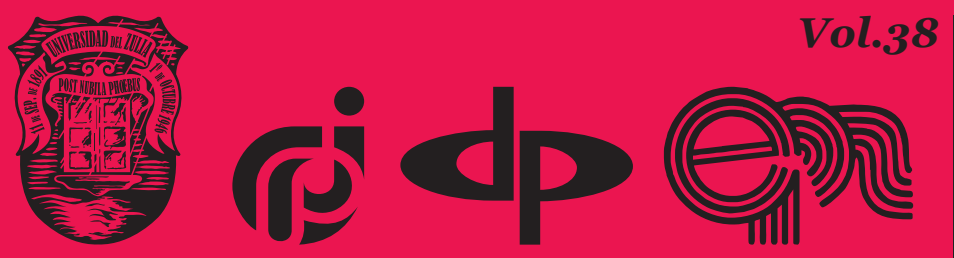

$N^{\circ}$ Especial 2da Parte 2020 


\title{
Features of Qualification and Prevention of Smuggling of Narcotic Drugs, Psychotropic Substances: their Precursors or Analogues
}

\author{
DOI: https://doi.org/10.46398/cuestpol.382e.28
}

\begin{abstract}
Khayrullina Rezeda Gazinurovna *
Kravchenko Olga Dmitrievna **

Tobolskaya Victoria Valerievna ***

Nedorezova Olga Yuryevna ${ }^{* * * *}$
\end{abstract}

\section{Abstract}

The article is dedicated to the consideration of factors influencing the state of the situation in Russia in the field of detection and repression of the smuggling of narcotic drugs, psychotropic substances, their precursors, and analogues. In the methodological field it is an analytical research based on documentary, close to legal hermeneutics. Specifically, thearticle analyses Russian legislation, offers options to solve problems in the field of smuggling narcotic drugs, psychotropic substances, their precursors, and analogues. The authors consider the real problems of countering the drug threat, which is currently a serious obstacle to the development of the state. By way of concluding the nature and magnitude of the negative consequences, illicit trafficking in narcotic drugs, psychotropic substances, their precursors, and analogues can be classified as direct threats to national security. Today, the issues of countering the illegal circulation of narcotic drugs, using modern information technologies, improving mechanisms to convert goods obtained from illicit drug trafficking into state revenue are relevant.

Keywords: drug trafficking; narcotics; classification of the crime; crime prevention; legal hermeneutics.

* PhD in Law, Associate Professor, Department of Legal and Social Sciences, Kazan Federal University Naberezhnye Chelny Institute. ORCID ID: https://orcid.org/oooo-0002-7865-3146. Email: RGHajrullina@kpfu.ru

** Senior Lecturer, Department of Legal and Social Sciences, Kazan Federal University Naberezhnye Chelny Institute, ORCID ID: https://orcid.org/oooo-0003-1682-0962. Email: olkrav666@mail.ru

*** PhD in Economics, Associate Professor, Department of Legal and Social Sciences, Kazan Federal University Naberezhnye Chelny Institute. ORCID ID: https://orcid.org/oooo-0003-4004-0456. Email: tabv.2007@mail.ru

***** PhD in Economics, Associate Professor, Department of Legal and Social Sciences, Kazan Federal University Naberezhnye Chelny Institute. ORCID ID: https://orcid.org/oooo-0002-6921-7940. Email: ned-ol@yandex.ru 
Khayrullina Rezeda Gazinurovna, Kravchenko Olga Dmitrievna, Tobolskaya Victoria Valerievna y Nedorezova Olga Yuryevna

362

Features of Qualification and Prevention of Smuggling of Narcotic Drugs, Psychotropic Substances: their Precursors or Analogues

\section{Características de calificación y prevención del contrabando de estupefacientes, sustancias psicotrópicas: sus precursores o análogos}

\section{Resumen}

El artículo está dedicado a la consideración de los factores que influyen en el estado de la situación en Rusia en el campo de la detección y represión del contrabando de estupefacientes, sustancias psicotrópicas, sus precursores y análogos. En lo metodológico se trata de una investigación analítica de base documental, próxima a la hermenéutica jurídica. Concretamente, el artículo analiza la legislación rusa, ofrece opciones para resolver problemas en el campo del contrabando de estupefacientes, sustancias psicotrópicas, sus precursores y análogos. Los autores consideran los problemas reales de contrarrestar la amenaza de las drogas, que actualmente es un serio obstáculo para el desarrollo del estado. A modo de conclusión por la naturaleza y la magnitud de las consecuencias negativas, el tráfico ilícito de estupefacientes, sustancias psicotrópicas, sus precursores y análogos se puede clasificar como amenazas directas a la seguridad nacional. Hoy son relevantes los temas de contrarrestar la circulación ilegal de estupefacientes, utilizando modernas tecnologías de la información, mejorando los mecanismos para convertir los bienes obtenidos del tráfico ilícito de drogas en ingresos estatales.

Palabras clave: narcotráfico; estupefacientes; calificación del delito; prevención del delito; hermenéutica jurídica.

\section{Introduction}

In Art. 43 of the National Security Strategy of the Russian Federation, among the main threats to public security, the activity of criminal organizations and groups, including transnational ones, associated with the illicit trafficking of narcotic drugs and psychotropic substances is named (National Security Strategy Of The Russian Federation: Approved. 2016. By Decree of The President Of The Russian Federation Of December 31. 2015).

One of the activities of such associations, as you know, is the smuggling of these funds and substances, their illegal movement from the territory of one state to another, which is a component of the international drug business (Melnikova, 2019).

Problems associated with drug trafficking in Russia and in the world are becoming more and more urgent and come to the fore in ensuring national 
security. The spread of narcotic drugs creates a real threat to the health of the population, the economic potential of the country, negatively affects the demographic situation, contributes to the decline of cultural and moral values in society (Fetkulov et al., 2018).

The greatest danger of illicit drug supply to the territory of the Russian Federation comes from organized criminal communities with significant financial potential and corrupt connections. Often, the funds received as a result of the sale of narcotic drugs are used to finance terrorism, extremism and other types of criminal activity (Razumov et al., 2019).

Customs restrictions in various countries were introduced as trade relations developed. This process was uneven and uneven, but everywhere it began with the establishment of customs bans, which were accompanied by the development of smuggling (Dubailo, 2019).

\section{Methods}

Used informational and analytical materials on the fight against drug smuggling carried out by customs authorities. The legal acts on the fight against drugs and on countering the financing of trade in illicit psychotropic and other narcotic substances are considered.

\section{Results and Discussion}

One of the short stories of the current Criminal Code of the Russian Federation is Art. 229.1, which provides for liability for the smuggling of narcotic drugs, psychotropic substances, narcotic plants, tools, and equipment used to obtain drugs.

The object of this crime is the state of health of the population, i.e. the state of health of an unlimited number of persons who live in a specific territory (in a region, city, country), bound by the rules, and also by the conditions of a joint hostel. In the case of illegal movement of drugs by crossing the Customs Border or the State Border, auxiliary (additional) objects are social relations that ensure the organization of customs identification of drugs imported into the territory of the Russian Federation. The optional objects of crime can be public relations, which ensure the protection of the life and The subject of a crime can be considered narcotic drugs, psychotropic substances that are under special control and used for the manufacture of drugs. 
Khayrullina Rezeda Gazinurovna, Kravchenko Olga Dmitrievna, Tobolskaya Victoria Valerievna y Nedorezova Olga Yuryevna

The signs of the objective side are set out in the criminal law on smuggling and are presented in the form of the nature of the action, the place and method of movement. This process is expressed in the movement of objects of contraband by crossing the customs border, the place is the customs border. All methods of illegal drug trafficking are identical to those previously indicated, there are no differences in this list.

The objective side of this crime is the illegal movement across the customs border of the Union of narcotic drugs, psychotropic substances, their precursors or analogues, plants containing narcotic drugs, psychotropic substances or their precursors, or their parts containing narcotic drugs, psychotropic substances or their precursors, instruments or equipment under special control and used for the manufacture of narcotic drugs or psychotropic substances.

The subjective side of drug smuggling is characterized by guilt in the form of direct intent. The subject of the crime is a common one (a sane individual who has reached the age of 16). The qualifying signs of drug smuggling are provided for by Part 2 of Art. 229.1 of the Criminal Code of the Russian Federation, namely: a) by a group of persons by prior agreement; b) by an official using his official position; c) in relation to narcotic drugs, psychotropic substances or their analogues, narcotic plants or their parts in a significant amount health of persons exercising customs or border control.

Particularly qualifying signs are provided for in parts 3 and 4 of this criminal law norm and establish responsibility for committing drug smuggling on a large scale, as well as for committing a crime on an especially large scale by an organized group using violence against a person exercising customs or border control.

The subject of the crime is narcotic drugs, psychotropic substances, their precursors or analogs, narcotic plants or their separate parts, tools or equipment under special control used for the manufacture of drugs. Illegal movement of drugs through the Customs or State border of the Russian Federation can be carried out by: - illegal import or export of drugs through the border of Russia; - false declaration or non-declaration of such substances; - providing inaccurate information about the transported products (with fraudulent use of documents or means of customs identification); - concealment of the transported goods or giving it a different look (using hiding places and various methods that complicate the detection of drugs by law enforcement agencies), etc. (Matkevich, 2020).

Illegal actions preceding or following the smuggling of drugs or their precursors (storage, processing, shipment, sale) entail additional qualifications in accordance with the relevant norms of the Special Part of the Criminal Code of the Russian Federation. 
The reasons and conditions for the smuggling of narcotic drugs (psychotropic substances) include:

1. excess profits and excess profits received by criminal groups (communities) as a result of the sale of drugs. In terms of profitability, such a business is comparable to illegal operations with oil, gas, timber, precious stones and metals, and weapons.

2. geopolitical and geographic determinants point to the location of Russia in the center of the Eurasian continent, which, combined with the transparency of its borders, creates an incentive to import (smuggle through its territory) drugs from neighboring states (Kyrgyzstan, Tajikistan, Azerbaijan) and far abroad (Afghanistan, Colombia, Holland, China, India and others).

3. imperfection of customs legislation and its law enforcement procedures can also be one of the factors causing the smuggling of narcotic drugs and psychotropic substances; a large number of sources of customs law, frequent changes and additions to Russian legislation, insufficient efficiency of administrative regulations (decision-making procedures by officials vested with powers in the field of customs regulation).

4. There are cases of corruption of employees of customs, border and other law enforcement agencies who are materially interested in the illegal transport of items and substances across the border of the Russian Federation. Such employees can contribute to the creation of fictitious customs terminals, forgery of customs documents, destruction of material evidence, unjustified termination of an administrative or criminal investigation.

5. Insufficient interaction of Russian customs (border) authorities with foreign law enforcement agencies on the problem of preventing smuggling and other offenses. As a rule, the interaction of such bodies is not of a systemic nature and is not based on mutual interest, despite the presence of a sufficiently developed regulatory framework for such cooperation (Cherevko and Loginov, 2017).

6. Crimes under Art. 229.1 of the Criminal Code of the Russian Federation, are committed not only by citizens of the Russian Federation, but also by foreign citizens and stateless persons. A number of ethnic criminal gangs specialize in the illegal supply of narcotic, psychotropic, potent substances to the territory of Russia.

Every third crime related to the illegal supply of drugs to Russia is committed by foreigners (Tagantsev, 1902).

Let us illustrate the judicial practice on this crime. By the verdict of the district court of the Saratov region of May 6, 2016, a citizen of the Russian 
Khayrullina Rezeda Gazinurovna, Kravchenko Olga Dmitrievna, Tobolskaya Victoria Valerievna y Nedorezova Olga Yuryevna

Federation, Ch.V.V., was found guilty of being as a passenger in a VAZ car and hiding a narcotic drug - cannabis (marijuana) in the left sleeve of an Olympic jacket wearing it with a total weight of 13.6 grams, illegally moved this drug through the State border of the Russian Federation with the member states of the customs Union within the framework of the EurAsEC, for which he was convicted under paragraph "c" part 2 of Art. 229.1.

From the analysis of materials from judicial practice, it is possible to single out cases when drug smuggling is recognized as insignificant. Thus, the Presidium of the Moscow City Court, considering criminal case No. $44 / \mathrm{u}-33 / 11$ in the order of supervisory proceedings, established that on February 11, 2010 at 10:05 a.m., citizen B., having arrived by plane from Delhi to Moscow, was detained at the customs post as there was a dark brown substance in her backpack that looked like a drug. The examination established that this substance is a narcotic drug (hashish) with a total weight of 0.06 grams. A criminal case was opened on this fact, and the perpetrator was convicted of drug smuggling. The higher court overturned the initial decisions and terminated the criminal case due to its insignificance.

According to the Presidium of the Moscow City Court, the actions of gr. B. do not have signs of significant danger, and the materials of the criminal case do not have sufficient data indicating that the actions of gr. B. caused harm to an individual, society or the state (Lavrinov, 2018).

Over the past year, the customs authorities, during the customs control of persons, vehicles and cargo, operational and search activities carried out both independently and in cooperation with Russian and foreign law enforcement agencies, have withdrawn from illegal circulation over $153 \mathrm{~kg}$ of narcotic drugs, psychotropic and potent substances ... 556 criminal cases were initiated on the facts of smuggling of narcotic and potent substances and their precursors, including 303 cases under article 229.1 of the Criminal Code of the Russian Federation.

In the course of customs control of persons, vehicles and cargo, operational-search activities carried out both independently and in cooperation with Russian and foreign law enforcement agencies, more than 2.4 tons of narcotic drugs, potent substances, and psychotropic substances were withdrawn from illegal circulation and their precursors, on the facts of the smuggling of narcotic drugs, potent substances and their precursors, 447 criminal cases were initiated based on the materials of the operational divisions of the customs, including 234 cases under Article 229.1. 


\section{Summary}

To the measures of prevention, detection, and suppression of crimes under Art. 229.1 of the Criminal Code of the Russian Federation, include:

creation of an effective system for protecting the territory of the Russian Federation from illegal import of narcotic, psychotropic, potent substances from near and far abroad.

- Improving measures for the effectiveness of border control, increasing the technical equipment of customs and border authorities.

- Liquidation of clandestine drug laboratories (infrastructure for illegal production, transportation, sale of drugs) in Russia.

- Identification of signs and suppression of the activities of transnational criminal organizations specializing in drug trafficking.

- Timely detection and recognition of new types of psychoactive substances (PAS) with their subsequent classification as narcotic or psychotropic drugs.

development and strengthening of international cooperation, implementation of coordinated interstate preventive, investigative, operational-search measures aimed at blocking the channels of illegal drug supply (Gracheva and Chuchaev, 2019).

\section{Conclusions}

Drug smuggling is a real disaster for the country, both economically and socially, causing harm, first of all, to the health and well-being of the country's citizens. The legislator, by his actions, is actively fighting this type of smuggling. As a rule, these are amendments to the Criminal Code of the Russian Federation. Difficulties also arise in the qualification of this type of crime.

As can be seen from the criminal-legal characteristics of smuggling in general, we can say that this type of crime is multifaceted and difficult to detect by customs officers. In the timely and successful detection of contraband lies the guarantee of national and economic security and the guarantor of the inevitability of punishment is fixed. 
Khayrullina Rezeda Gazinurovna, Kravchenko Olga Dmitrievna, Tobolskaya Victoria Valerievna y Nedorezova Olga Yuryevna

Features of Qualification and Prevention of Smuggling of Narcotic Drugs, Psychotropic Substances: their Precursors or Analogues

\section{Acknowledgements}

The work is performed according to the Russian Government Program of Competitive Growth of Kazan Federal University.

\section{Bibliographic References}

CHEREVKO, Villiam; LOGINOV, Elandra. 2017. "Improvement of Liability Measures for Evasion from Customs Payments" In: Contemporary Problems of Social Work. Vol. 3, No. 4(12), pp. 13-19.

DUBAILO, Yuldna. 2019. Combating Smuggling as a Mean of State Protectiona. Risks and Safety In Rapidly Changing World. Materials of the VII international scientific conference.

FETKULOV, Alikjan; KOILYBAYEVA, Alex; ABEUOVA, Altynai Tanatkanovna. 2018. "Activities of Customs Bodies in the Sphere of Anti-Action Illicit Trafficking in Drugs Republic of Kazakhstan" In: Actual Problems of Modernity. Vol. 2, No. 20, pp. 35-38.

GRACHEVA, Yulenda; CHUCHAEV, Albertm. 2019. "Smuggling and "smuggling" crimes: similarities and differences" In: Union of Forensic Scientists and Criminologists. Vol. 1, pp. 45-54.

LAVRINOV, Vitaly Valerievich. 2018. Correlation of smuggling and evasion of customs payments in modern Russian criminal legislation. Features of state regulation of foreign economic activity in modern conditions. Materials of the V All-Russian scientific-practical conference.

MATKEVICH, Yamour. 2020. “Concept, Types Of International Cooperation In The Field Of Smuggling Prevention” In: Danish Scientific Journal. Vol. 3 , No. 3, pp. 19-22.

MELNIKOVA, Anastasia Alexeevna. 2019. Improvment of Customs Management System. In: Young Scholars 'Research in the Humanities. Proceedings of the V International conference for young researchers. Saratov, Russia.

NATIONAL SECURITY STRATEGY OF THE RUSSIAN FEDERATION: APPROVED. 2016. by decree of the President of the Russian Federation of December 31. 2015 No. 683. Collected Legislation of the Russian Federation, 1, Part II. Art. 212. 
RAZUMOV, Pavel; SMIRNOV, Ikana; CHERKESOVA, Larissa; KOROCHENTSEV, Denis. 2019. "Crime Activity In The Shadow Web And Ways To Combat It” In: Österreichisches Multiscience Journal. Vol. 17, No. 1, pp. 54-58.

TAGANTSEV, Nattalie. 1902. Russian criminal law. Part is common. St. Petersburg, Russia. 

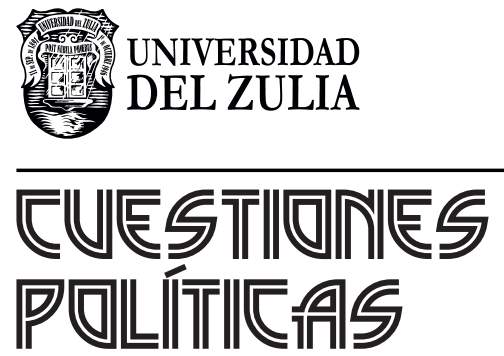

Vol.38 NEspecial

Esta revista fue editada en formato digital y publicada en diciembre de 2020, por el Fondo Editorial Serbiluz, Universidad del Zulia. Maracaibo-Venezuela 